\title{
PROFIL HORMON ESTRADIOL 17ß DAN INDUKSI HORMON OVAPRIM DALAM PEMIJAHAN BUATAN IKAN SELAIS (Ompok hypophthalmus Blkr)
}

\author{
PROFILE OF ESTRADIOL 17B HORMONE (GTH) AND \\ INDUCTION OF OVAPRIM HORMONE IN SPAWNING BY \\ SELAIS (Ompok hypophthalmus Blkr)
}

\author{
Nasril Ismail ${ }^{1}$, Usman M. Tang ${ }^{1}$, dan Henni Syawal ${ }^{1}$ \\ 1 Kekhususan Budidaya Perairan Magister Ilmu Kelautan, Fakultas Perikanan dan Kelautan, \\ Universitas Riau, Jl. HR Soebrantas Km 12,5 Simpang Baru, Panam-Pekanbaru Indonsia 28293 \\ Correspondence Author : ismail.nasril@yahoo.com
}

A R T I CLE IN F O

Submitted: 05 April 2018

Revised : 15 Mei 2018

Approved: 10 Juni 2018
Kata kunci :

Estradiol, ovulasi, dan penetasan

\begin{abstract}
The purpose of this study was analyze the amount of estradiol and tostesterone hormone in the body of the selais (O. hypophthalmus Blkr) fish the mature gonads and the number of ovaprim hormone doses used based on the amount of hormone in the fish body on ovulatory success and spawning of fish Selais. The study used a complete randomized design consisting of four treatments and three replicates consisting of controls, $0.05 \mathrm{~mL} / 100$ grams of body weight, 0.07, mL / 100 gram body weight, $0.09 \mathrm{~mL} / 100$ gram body weight and $0,11 \mathrm{~mL} / 100$ gram body weight. The results showed that the concentrations of estradiol-17 $\beta$ hormone in blood ranged from $199.13 \mathrm{pg} / \mathrm{mL}$ to $236.28 \mathrm{pg} / \mathrm{mL}$ before and after ovulation of each treatment ranging from $273.97 \mathrm{pg} / \mathrm{mL}$ to $873.65 \mathrm{pg} / \mathrm{mL}$ and after ovulation ranged from $0.71 \mathrm{pg} / \mathrm{mL}$ to $1.78 \mathrm{pg} / \mathrm{mL}$ Whereas for other parameters obtained the results of the latency $11.27 \pm 0.252$ to $13.40 \pm 1,95$ hours, fecundity $1919 \pm 0.546$ to $3243 \pm 0.420$ grains, egg diameter after ovulation $1.32 \pm 0.29$ to $1.32 \pm 0.29 \mathrm{~mm}$, fertilization rate of $28.99 \pm 157$ to $36.54 \pm 148 \%$, hatching rate of $40.79 \pm 071$ to $36.54 \pm 148 \%$ and the survival rate 3 day $75.82 \pm 047$ to $84.53 \pm 0.36 \%$.
\end{abstract}

Abstrak

Tujuan dari penelitian ini adalah menganalisis jumLah hormon estradiol dalam tubuh ikan selais (O. hypophthalmus Blkr) yang matang gonad dan jumLah dosis hormon ovaprim yang digunakan berdasarkan jumlah hormon dalam tubuh ikan terhadap keberhasilan ovulasi dan pemijahan ikan Selais. Penelitan ini menggunakan rancangan acak lengkap terdiri dari empat perlakuan dan tiga ulangan terdiri dari kontrol, ovaprim $0,05 \mathrm{~mL} / 100$ gram berat tubuh, 0,07 , $\mathrm{mL} / 100$ gram berat tubuh, $0,09 \mathrm{~mL} / 100$ gram berat tubuh dan 0,11 $\mathrm{mL} / 100$ gram berat tubuh. Hasil penelitian menunjukkan bahwa Konsentrasi hormon estradiol-17 $\beta$ dalam darah berkisar 199,13 $\mathrm{pg} / \mathrm{mL}$ sampai $236,28 \mathrm{pg} / \mathrm{mL}$ sebelum dan sesudah ovulasi setiap perlakuan menjadi berkisar $273,97 \mathrm{pg} / \mathrm{mL}$ sampai $873,65 \mathrm{pg} / \mathrm{mL}$ Sedangkan terhadap parameter lain diperoleh hasil yaitu waktu laten $11,27 \pm 0,252$ sampai $13,40 \pm 1,95$ jam, fekunditas $1919 \pm 0.546$ sampai $3243 \pm 0.420$ butir, diameter telur sesudah ovulasi $1.32 \pm 0.29$ sampai $1.32 \pm 0.29 \mathrm{~mm}$, derajat pembuahan $28.99 \pm 157$ sampai $36.54 \pm 148 \%$, derajat penetasan $40.79 \pm 071$ sampai $36.54 \pm 148 \%$ dan kelangsungan hidup larva 3 hari $75.82 \pm 047$ sampai $84.53 \pm 0.36 \%$. 


\section{PENDAHULUAN}

Data Fishbase menyebutkan, Indonesia berada diurutan ketiga sebagai negara yang memiliki spesies ikan air tawar terbanyak di dunia, setelah China (urutan kedua) dan Brazil (urutan pertama). Total spesies ikan air tawar di Perairan Indonesia adalah 1.300 spesies, dan 440 diantaranya adalah spesies endemik ikan air tawar (Budiman et al., 2002). Salah satu Ikan endemik yang terdapat di Provinsi Riau Sumatera adalah Ikan selai s (Ompok hypophthalmus Blkr) adalah jenis ikan air tawar yang banyak dijumpai di perairan umum yang terdapat pada 4 sungai terbesar di daerah Riau. yaitu di Sungai Siak, Sungai Rokan, Sungai Indragiri dan Sungai Kampar

Kelestarian ikan selais dari perairan alam perlu dijaga, namun kebutuhan masyarakat terhadap ikan ini perlu pula dipenuhi. Suatu cara yang dapat dilakukan agar kebutuhan masyarakat terhadap ikan selais tetap dapat terpenuhi dan kelestariannya dari alam tetap terjaga maka perlu ditemukan teknologi pembenihan yang tepat melalui pemijahan buatan dengan menggunakan hormon ovaprim, yang selanjutnya melakukan teknologi budidaya yang tepat untuk memproduksi ikan selais sehingga tidak lagi tergantung dari hasil tangkapan di alam.

Hormon reproduksi yang digunakan untuk membantu proses pemijahan adalah LHRH-a dan 17- $\alpha$ metil testosteron. Fungsi dari LHRH-aadalah merangsang pelepasan hormon gonadotropin (Zairin, 2003). Berdasarkan penelitian Subagja (2006), penggunaan LHRH-a dengan kombinasi dosis 17- $\alpha$ metil testosteron dapat meningkatkan konsentrasi estradiol dan testosteron dalam plasma darah ikan balashark (Balantiocheilus melanopterus) serta efektif untuk kelangsungan perkembangan gonad karena 17- $\alpha$ metil testosterone sebagai penyedia testosteron yang berguna untuk merangsang spermiasi spermatozoa dan tingkah laku pemijahan pada ikan. Hormon-hormon yang selama ini digunakan untuk membantu dalam reproduksi ikan merupakan bahan kimia yang umumnya berbahaya bila masuk kedalam jaringan tubuh manusia, untuk itu perlu adanya bahan alami untuk menggantikan dalam penggunaan bahan kimia tersebuat tanpa menghilangkan fungsinya.

Tujuan dari penelitian ini adalah Menganalisis jumlah hormon estradiol dan tostesteron dalam tubuh ikan selais (Ompok hypophthalmus Blkr) yang matang gonad dan mentukan jumlah dosis hormon ovaprim yang digunakan berdasarkan jumlah hormon dalam tubuh ikan terhadap keberhasilan ovulasi dan pemijahan ikan Selais.

\section{METODE PENELITIAN}

Ikan uji yang digunakan adalah induk jantan ikan selais (Ompok hypophthalmus Blkr) yang matang gonad berukuran kurang lebih 100 gram sebanyak 15 ekor dan untuk induk betina sebanyak 15 ekor, induk berasal dari Sungai Kampar. Hormon sebagai obat perangsang yang digunakan adalah ovaprim sedangkan alkohol $70 \%$ untuk mensterilkan alat dan kalium permanganate (PK) sebagai bahan desinfektan untuk wadah.

Peralatan yang digunakan dalam penelitian ini adalah alat serok ikan, timbangan, mangkuk kecil, petridisk, saringan santan, kateter canula, bulu ayam, sentrifuse, pipet, spuit, spektrofotometer, dan tissue.

Wadah yang digunakan untuk ikan uji adalah satu buah bak ukuran $200 \times 100$ x $75 \mathrm{~cm}$ untuk penampungan induk sebelum digunakan sebagai ikan uji dan akuarium sebanyak 30 unit dengan ukuran $60 \times 40 \times 40 \mathrm{~cm}$ Setiap wadah dilengkapi dengan sistem aerasi sebagai penyuplai oksigen.

Penelitian ini dilakukan secara eksprimen dengan rancangan penelitian pemijahan dan ovulasi akhir ikan selais. Dosis penelitian berdasarkan kepada dosis yang digunakan pada uji pendahuluan, yaitu $0,09 \mathrm{ml}$ dengan berat ikan 100 
gram. Rancangan yang digunakan Rancangan Acak Lengkap (RAL), yang terdiri atas 4 perlakuan, yaitu Kontrol $\mathrm{NaCl}$, Hormon ovaprim $0,05 \mathrm{ml}, 0,07 \mathrm{ml}$, $0,09 \mathrm{ml} / 100$ gram dan $0,11 \mathrm{ml} / 100$ gram.

\section{Prosedur penelitian}

Pengukuran konsentrasi hormon estradiol$17 \beta$ dan testosteron dalam darah dilakukan sebelum penyuntik hormon ovaprim pada induk ikan yang matang gonad dan sesudah pemijahan. Mekanisme pengambilan sampel darah adalah :

Ikan sebelum diambil darahnya, terlebih dahulu dibius dengan menggunakan minyak cengkeh dengan dosis $0,5 \mathrm{cc} / 10$ liter air. Setelah ikan pingsan, darahnya diambil pada bagian linea lateralis arah caudal sebanyak $1 \mathrm{ml}$ dengan menggunakan syringe kapasitas $3 \mathrm{ml}$ yang sudah diberi antikoagulan (larutan Natrium Citrat 3,8\%), kemudian dimasukkan ke dalam microtube volume $1.5 \mathrm{ml}$. Darah yang ditampung dalam microtube disentrifus pada kecepatan 10.000 rpm selama 5-10 menit, untuk mendapatkan plasma. Plasma darah diambil dan dimasukkan ke dalam microtube baru. Bila pengukuran supernatan plasma tidak dilakukan secara langsung, sampel dapat disimpan dalam freezer pada suhu $-20{ }^{\circ} \mathrm{C}$.

Pengukuran konsentrasi hormon estradiol$17 \beta$ dan testosteron dalam plasma darah ikan Selais dilakukan dengan menggunakan metode ELISA di Laboratorium Balai Penelitian dan Pengembangan Budidaya Ikan Hias Depok Jawa Barat.

\section{HASIL DAN PEMBAHASAN Profil hormon estradiol-17ß}

Konsentrasi hormon estradiol-17 $\beta$ plasma darah induk ikan selais betina pada perlakuan ovaprim sebelum penyuntikan dan sesudah ovulasi mengalami peningkatan (Gambar 1), sebaliknya pada perlakuan kontrol tanpa menggunakan ovaprim menunjukkan angka 209,36 (Gambar 1). Pada perlakuan ovaprim menunjukkan kisaran konsentrasi estradiol sebelum berkisar 199,13 pg/mL sampai $236,28 \mathrm{pg} / \mathrm{mL}$ dan sesudah ovulasi setiap perlakuan menjadi berkisar 273,97 pg/mL sampai 873,65 $\mathrm{pg} / \mathrm{mL}$ sedangkan yang paling tinggi peningkatan, yaitu dari $215,75 \mathrm{ng} / \mathrm{mL}$ menjadi $873,65 \mathrm{pg} / \mathrm{mL}$.

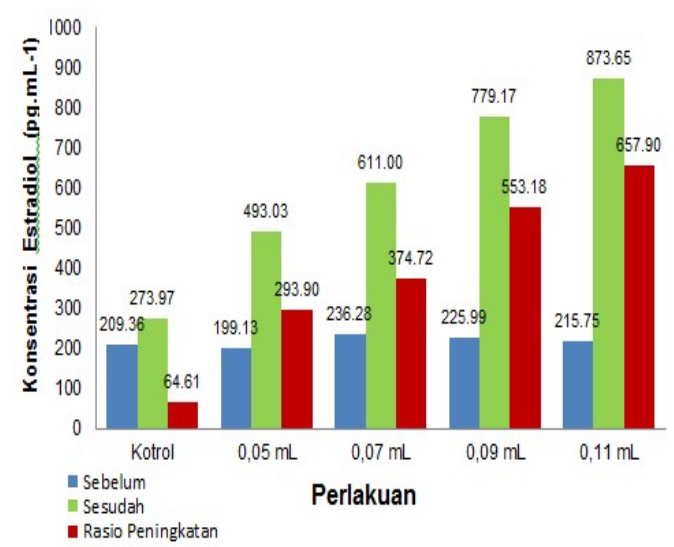

Gambar 1. Konsentrasi estradiol-17ß dalam plasma darah ikan selais betina sebelum penyuntikan, sesudah induksi hormon Ovaprim dan rasio peningkatan.

Hasil penelitian menunjukkan bahwa perlakuan $0,11 \mathrm{~mL}$ merupakan perlakuan terbaik pada penelitian ini. Hasil pada parameter pertama, yaitu konsentrasi estradiol-17 $\beta$, membuktikan bahwa perlakuan $0,11 \mathrm{~mL}$ dapat menginduksi ovulasi dan pemijahan ikan selais secara buatan. Konsentrasi estradiol-17 $\beta$ dalam plasma darah ikan selais menunjukkan pada perlakuan 0,05 , 0,07 dan $0,09 \mathrm{~mL}$ mengalami peningkatan (Gambar 1). Peningkatan estradiol 17 menyebabkan oosit mengalami germinal vesicle germinal vesicle (GVBD) dan berakhir pada ovulasi serta pemijahan. Kadar hormon gonadotropin yang relatif stabil bahkan cenderung meningkat sepanjang siklus pemijahan juga merupakan fenomena yang menarik karena keberhasilan pemijahan secara tidak langsung memerlukan induksi dari hormon gonadotropin (Yaron, 1995 ; Barnier et al. 2009). Proses pematangan gonad diprediksi melalui kadar testosteron dan estradiol-17 $\beta$ terhadap perkembangan oosit (Mackenzie et al. 1989). Oleh karena itu kadar steroid plasma dapat digunakan 
sebagai indikator dari pematangan gonad (Zairin et al. 1992).

Estradiol adalah steroid yang sangat penting terutama untuk ikan betina yang sedang mengalami proses vitelogenesis. Konsentrasi estradiol merupakan jumlah kandungan hormon estradiol pada ikan betina pada plasma darah untuk merangsang hati mensintesis vitelogenin. Pada perlakuan hormon ovaprim $(0,05,0,07,0,09$, dan $0,11 \mathrm{~mL})$ terjadi peningkatan nilai konsentrasi estradiol dari sebelum dan pada saat sesudah ovulasi (Mahdaliana, 2014). Peningkatan estradiol-17 $\beta$ yang signifikan disebabkan pengaruh kinerja enzim aromatase yang meningkat dengan penyuntikkan perlakuan hormon ovaprim, sehingga pengubahan testosteron menjadi estradiol-17 $\beta$ akan semakin cepat.

\section{Hubungan Konsentrasi Hormon} Dengan Jumlah Dosis yang Disuntikan terhadap Keberhasilan Pemijahan

Perlakuan dengan menggunakan hormon ovaprim $(0,05,0,07,0,09$, dan $0,11 \mathrm{~mL}$ ) dan perlakuan kontrol tidak menggunakan hormon ovaprim. Pada ikan selais betina menggunakan ovaprim terjadi ovulasi, sedangkan pada perlakuan kontrol tidak terjadi ovulasi (Tabel 1).

Tabel 1. Tingkat ovulasi ikan selais (Ompok hypopthalamus Blkr) betina pada induksi ovulasi dan pemijahan buatan

\begin{tabular}{|c|c|c|c|c|c|}
\hline \multirow{2}{*}{ Parameter } & \multicolumn{5}{|c|}{ Dosis Ovaprim } \\
\hline & Control & $0,05 \mathrm{~mL}$ & $0,07 \mathrm{~mL}$ & $0,09 \mathrm{~mL}$ & $0,11 \mathrm{~mL}$ \\
\hline Waktu laten & $0^{\circ}$ & $13.25 \pm 0.591^{\circ}$ & $13.13 \pm 0.416^{\circ}$ & $12.10 \pm 0.415^{\circ}$ & $11.27 \pm 0.252^{\circ}$ \\
\hline $\begin{array}{l}\text { Jumlah } \\
\text { teluryang } \\
\text { ovulasi }\end{array}$ & $0^{\circ}$ & $1919 \pm 0.546^{\circ}$ & $2631 \pm 0.745^{\circ}$ & $2752 \pm 0.625^{\circ}$ & $3243 \pm 0.420^{\circ}$ \\
\hline $\begin{array}{l}\text { Diameter } \\
\text { telur } \\
\text { (sebelum } \\
\text { injeksi) }\end{array}$ & $1.00^{\circ}$ & $1.07 \pm 036^{\circ}$ & $1.05 \pm 011^{\circ}$ & $1.07 \pm 029^{\circ}$ & $1.05 \pm 0.050^{\circ}$ \\
\hline $\begin{array}{l}\text { Diameter } \\
\text { telur } \\
\text { (sesudah } \\
\text { ovulasi) }\end{array}$ & $0^{3}$ & $1.35 \pm 0.025^{\circ}$ & $1.33 \pm 0.29^{\circ}$ & $1.33 \pm 0.29^{\circ}$ & $1.35 \pm 0.025^{b}$ \\
\hline $\begin{array}{l}\text { Derajat } \\
\text { pembuahan }\end{array}$ & $0^{2}$ & $28.99 \pm 157^{\circ}$ & $32.86 \pm 238^{\circ \mathrm{c}}$ & $32.58 \pm 178^{\circ}$ & $36.54 \pm 148^{\mathrm{c}}$ \\
\hline $\begin{array}{l}\text { Derajat } \\
\text { penetasan }\end{array}$ & $0^{2}$ & $40.79 \pm 071^{\circ}$ & $46.01 \pm 090^{\circ}$ & $46.39 \pm 144^{\circ}$ & $61.72 \pm 064^{c}$ \\
\hline $\begin{array}{l}\text { Kelangsung } \\
\text { hidup larva } \\
3 \text { bari(\%) }\end{array}$ & $0^{\circ}$ & $75.82 \pm 047^{\circ}$ & $78.26 \pm 073^{c}$ & $81.47 \pm 127^{c}$ & $84.53 \pm 0.36^{\circ}$ \\
\hline Ket & $\begin{array}{l}\text { Huru } \\
\text { kolom } \\
\text { perbec }\end{array}$ & $\begin{array}{l}\text { supersc } \\
\text { di at } \\
\text { aan anta }\end{array}$ & $\begin{array}{l}\text { ript yang } \\
\text { as ment } \\
\text { ir perlaku }\end{array}$ & $\begin{array}{l}\text { tidak sc } \\
\text { unjukkan } \\
\text { uan }\end{array}$ & $\begin{array}{r}\text { ama pada } \\
\text { adanya }\end{array}$ \\
\hline
\end{tabular}

Tabel 1 hasil penelitian ini diketahui bahwa ikan betina yang diberi perlakuan hormon ovaprim (dosis 0,05, 0,07, 0,09, dan $0,11 \mathrm{~mL}$ ) dapat memijah secara buatan dengan cara stripping, sedangkan pada perlakuan kontrol ikan tidak memijah selama 24 jam pengamatan.

\section{Waktu Laten}

Perhitungan waktu laten pada penelitian ini yaitu jarak waktu dari dilakukannya induksi hormon ovaprim hingga terjadinya ovulasi yang dideteksi dengan adanya keberhasilan telur. Induksi ovulasi pada ikan selais dengan perlakuan ovaprim dapat merangsang ovulasi dengan persentase keberhasilan mencapai $100 \%$ (Gambar 2). Pada penyuntikan dengan $\mathrm{NaCl}$ pada control ternyata tidak merangsang terjadinya ovulasi pada ikan selais.

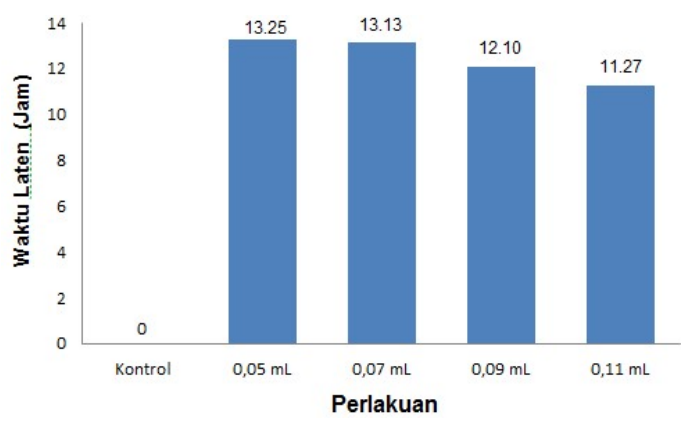

Gambar 2. Rata-rata waktu laten ikan Selais (Ompok hypopthalamus Blkr) yang diberi perlakuan menggunakan hormon Ovaprim.

Berdasarkan hasil penelitian ini diketahui bahwa masa laten yang dibutuhkan untuk mencapai ovulasi dari telur postvitellogenic berbeda-beda antar perlakuan dan penelitian ini menunjukkan bahwa semakin meningkat dosis ovaprim yang diinduksikan (dari 0,05, 0,07, 0,09 dan $0,11 \mathrm{~mL}$ ) menghasilkan waktu laten yang lebih singkat.

Hasil perbandingan waktu laten pada penelitian ini memperlihatkan bahwa waktu laten yang terpanjang dengan waktu laten tersingkat, terdapat selisih rata-rata 1,98 jam untuk perlakuan dosis induksi ovaprim 0,05 dan $0,11 \mathrm{~mL}$. Perbedaan 
waktu laten dalam penelitian ini diduga karena pengaruh dosis hormon yang diinduksikan. Hal ini dapat dijelaskan bahwa induksi ovaprim dalam dosis yang lebih besar terhadap ikan selais berperan dalam memberikan semakin besarnya stimulasi dan sekresi gonadotropin. Selanjutnya sekresi gonadotropin dalam hal ini GTH II atau LH sebagai produk dari kelenjar hipofisis akan dialirkan melalui darah. Gonadotropin dalam kadar yang lebih tinggi akan lebih cepat merangsang kematangan oosit tahap akhir serta pecahnya folikel (ovulasi) melalui perannya dalam menstimulasi sekresi 17,20-P dari folikel postvitellogenic.

\section{Ovulasi}

Jumlah telur yang berhasil dipijahkan induk betina ikan selais antar perlakuan induksi hormon berbeda. Pada perlakuan $0,11 \mathrm{~mL}$ yang diinduksi dengan hormon ovaprim dan memijah secara buatan (stripping) menghasilkan jumlah telur yang tertinggi (3243 butir). Sedangkan pada perlakuan dosis $0,05 \mathrm{~mL}$ ikan memijah dan menghasilkan telur yang paling rendah (1919 butir), dan pada kontrol $\mathrm{NaCl}$ tidak terjadi pemijahan (Gambar 3).

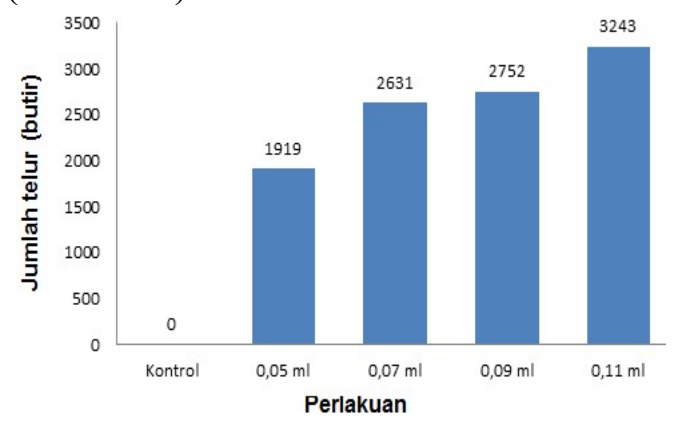

Gambar 3. Rata-rata jumlah telur ikan selais (Ompok hypopthalamus Blkr) yang dihasilkan pada induksi pemijahan buatan.

Berdasarkan Gambar 3 hasil penelitian ini diketahui bahwa semakin meningkat dosis ovaprim yang diinduksikan (dari 0,05, 0,07, 0,09 dan $0,11 \mathrm{~mL}$ ) menghasilkan jumlah telur lebih banyak. Pemberian dosis yang tinggi dapat mempercepat dan memicu terjadinya ovulasi. Hal ini dikarenakan, ovaprim berperan dalam menurunkan aktivitas aromatase dalam gonad akibatnya produksi estrogen-17 $\beta$ turun dan meningkatkan produksi testosteron, hal tersebut merupakan awal sinyal balik positif terhadap LH sehingga proses pematangan oosit akan berlangsung lebih cepat.

Ovulasi merupakan proses keluarnya sel telur folikel ke dalam lumen ovarium atau rongga perut. Nagahama (1987) menyatakan bahwa proses ovulasi terdiri dari beberapa tahapan. Pada tahap awal lapisan folikel melepaskan diri dari oosit, pada saat akan terjadi ovulasi, mikrofili pada kedua permukaan tersebut sedikit demi sedikit terpisah, hal tersebut dimungkinkan dilakukan oleh enzim proteolitik. Dalam setiap perkembangan secara biologi termasuk oosit ikan, perkembangan antara satu fase ke fase yang berikutnya membutuhkan waktu tertentu.

\section{Diameter telur}

Diameter telur sebelum diberi perlakuan induksi hormon dan setelah pemijahan mengalami peningkatan pada semua perlakuan. Pada perlakuan kontrol $\mathrm{NaCl}$ tidak memijah, diameter telur sebelum penyuntikan 1,00 mm (Gambar $4)$.

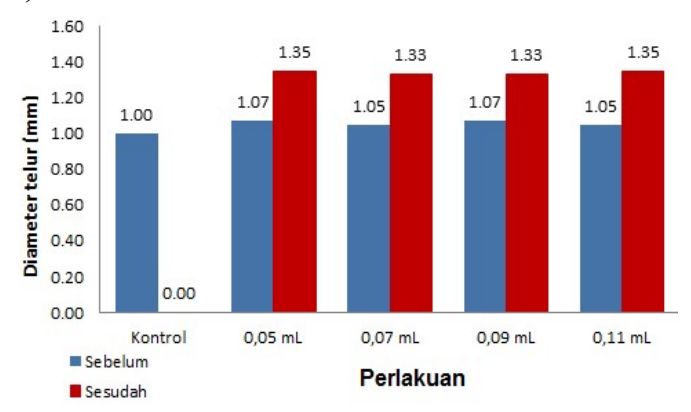

Gambar 4. Diameter telur sebelum penyuntikan hormon ovaprim dan sesudah pemijahan.

Berdasarkan Gambar 4 hasil penelitian ini diketahui bahwa diameter telur yang tertinggi pada pemijahan buatan adalah pada perlakuan dosis 0,05 dan 0,11 $\mathrm{mL}$ yaitu $1,35 \mathrm{~mm}$ sedangkan pada perlakuan $0,07 \mathrm{~mL}$ dan $0,09 \mathrm{~mL}$ 
menunjukkan ukuran diameter yang paling rendah $(1,33 \mathrm{~mm})$ yang memijah dengan distripping. Diameter telur ikan selais hasil induksi ovulasi dan pemijahan secara buatan menggunakan ovaprim menunjukkan adanya perbedaan yang signifikan sebelum maupun sesudah ovulasi antara perlakuan. Diameter telur akan berbeda antar pelakuan yang diberikan hormon ovaprim. Menurut (Elvyra $\mathrm{R}$ et al., 2010) pengukuran diameter telur ikan selais adalah berkisar $0,41-1,13 \mathrm{~mm}$. Hal ini terjadi karena diameter telur dapat dipengaruhi oleh induksi hormon yang diberikan pada induk. Ukuran diameter telur dipengaruhi oleh banyaknya vitelogenin yang tersimpan di dalamnya yang terjadi ketika proses perkembangan telur. Namun demikian, menurut Effendie (1997) tidak semua ikan memiliki hubungan yang berbanding lurus antara fekunditas dan diameter sel telur. Ukuran telur ikan berkaitan dengan tingkat kematangan gonad pada induk. Semakin tinggi tingkat kematangan gonad maka ukuran telur semakin membesar dan akan berhenti setelah mencapai ukuran tertentu (maksimal).

\section{Derajat pembuahan}

Derajat pembuahan telur ikan selais pada perlakuan hormon ovaprim $(0,11)$ lebih tinggi dibandingkan perlakuan $(0,07)$ dan $(0,09)$ maupun $(0,05)$. Derajat pembuahan telur berkisar antara $28.99 \%$ dan $36.54 \%$ (Gambar 5).

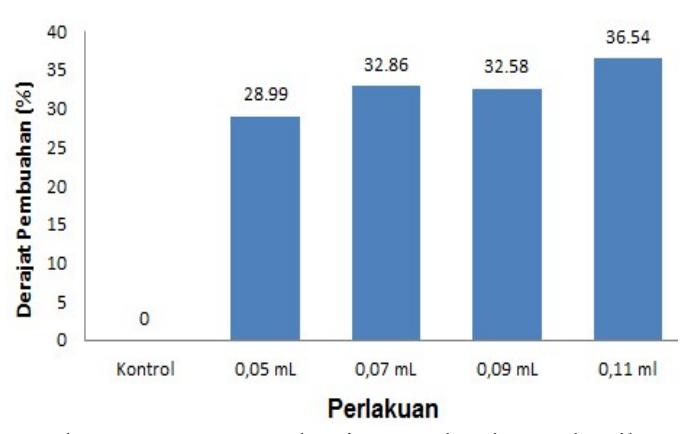

Gambar 5. Rata-rata derajat pembuahan telur ikan selais (Ompok. Hypopthalamus Blkr) pada induksi ovulasi dan pemijahan buatan.
Berdasarkan Gambar 6 hasil pembuahan telur ikan selais tertinggi terdapat pada induk ikan selais yang diinduksi dengan perlakuan $0,011 \mathrm{ml}$ yaitu sebesar $36.54 \%$ dan derajat pembuahan terendah terjadi pada ikan yang diinduksi perlakuan $0,05 \mathrm{ml}$ yaitu, $28.99 \%$. Selanjutnya $0,09 \mathrm{ml}$, yaitu $32.58 \%$ dan 0,07 yaitu $32.86 \%$. Dalam hal ini diduga karena adanya pengaruh efektivitas hormon yang diberikan pada perlakuan induksi dengan dosis yang berbeda.

Pembuahan atau fertilisasi merupakan penggabungan gamet, dimana penggabungan ini merupakan mata rantai awal dan sangat penting pada proses fertilisasi. Penggabungan gamet biasanya disertai dengan pengaktifan telur. Selama fertilisasi dan pengaktifan, telur-telur ikan teleostei mengalami reaksi kortikal. Kortikal alveoli melebur, melepaskan cairan koloids, dan selanjutnya memulai pembentukan ruang periviteline (Kjorsvik E et al. 1990). Kortikal alveoli muncul setelah terjadinya fertilisasi dan reaksi kortikal yang tidak lengkap artinya menunjukkan kualitas telur yang buruk. Beberapa hal yang mempengaruhi pembuahan adalah berat telur ketika terjadi pembengkakan oleh air, $\mathrm{pH}$ cairan ovari, dan konsentrasi protein (Lahnsteiner et al. 2001).

\section{Derajat penetasan}

Induksi pemijahan buatan secara hormon ovaprim pada perlakuan $0,11 \mathrm{~mL}$ menunjukkan derajat penetasan yang tertinggi yaitu $61.72 \%$ dan yang terendah adalah pada perlakuan $0,05 \mathrm{~mL}$ yaitu $40.79 \%$ (Gambar 6). 


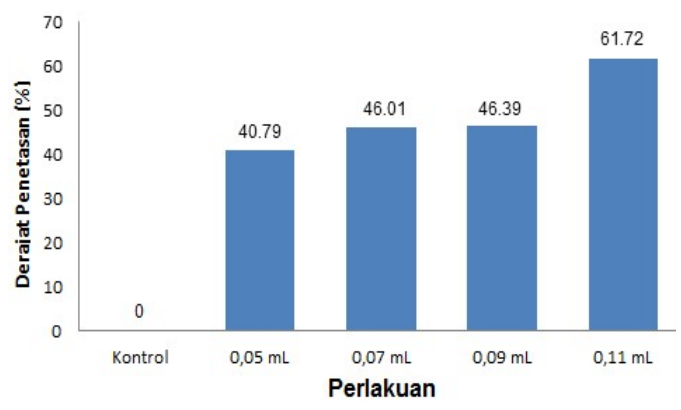

Gambar 6. Rata-rata derajat penetasan telur ikan selais (Ompok hypopthalamus Blkr) pada induksi ovulasi dan Pemijahan buatan.

Berdasarkan Gambar 6 pada penelitian ini didapatkan hasil bahwa derajat penetasan telur tertinggi ditemukan pada perlakuan dosis $0,11 \mathrm{~mL}$ dengan rataan derajat penetasan telur sebesar $61.72 \%$, Berdasarkan hal tersebut dapat dikatakan bahwa terdapat kecenderungan meningkatnya perolehan hasil penetasan larva seiring dengan peningkatan dosis perlakuan induksi ovaprim, tetapi secara statistika tidak terdapat pengaruh antar dosis perlakuan ovaprim.

Pada penelitian menunjukkan derajat penetasan telur ikan selais yang disuntik dengan ovaprim dipengaruhi oleh derajat pembuahan telur. Seperti yang dinyatakan oleh Oyen et al. (1991) bahwa prosentase daya tetas telur selalu ditentukan oleh prosentase fertilitas telur, dimana semakin tinggi prosentase fertilitas telur maka akan semakin tinggi pula prosentase daya tetas telur, kecuali bila ada faktor lingkungan yang mempengaruhi seperti perubahan suhu yang mendadak, oksigen dan $\mathrm{pH}$.. Secara umum kualitas telur yang baik dapat dilihat dari derajat penetasan telur.

\section{Kelangsungan hidup}

Kelangsungan hidup (TKH) larva ikan selais umur 3 hari berkisar 75,82$84,53 \%$ (Gambar 7).

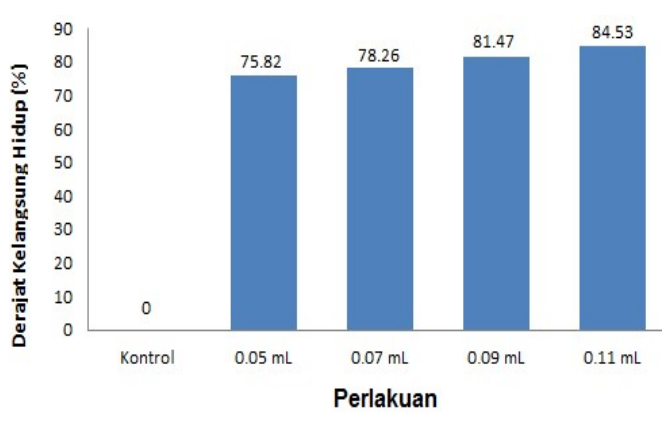

Gambar 7. Rata-rata kelangsungan hidup larva ikan selais (Ompok hypopthalamus $\mathrm{Blkr}$ )

Berdasarkan Gambar 7 hasil penelitian diketahui kelangsungan hidup ikan selais tertinggi terdapat pada induk ikan selais yang diinduksi dengan perlakuan $0,11 \mathrm{~mL}$ yaitu sebesar $84.53 \%$ dan kelangsungan hidup terendah terjadi pada ikan yang diinduksi perlakuan 0,05 mL yaitu $75.82 \%$. Selanjutnya $0,09 \mathrm{~mL}$ yaitu $78.26 \%$ dan $0,07 \mathrm{~mL}$ yaitu 81.47 $\%$. Dalam hal ini diduga karena adanya pengaruh efektivitas hormon yang diberikan pada perlakuan induksi dengan dosis yang berbeda.

Berdasarkan uji Newman-Keuls diketahui terdapat perbedaan pengaruh yang sangat nyata antar perlakuan dosis 0,11 $\mathrm{mL}$ dangan 0,07 dan $0,09 \mathrm{~mL}$ atau antara perlakuan dosis 0,07 dengan 0,09 $\mathrm{mL}$, tidak terdapat perbedaan yang nyata antara kelompok perlakuan dosis induksi. Kenyataan ini erat kaitannya dengan kandungan kuning telur. Kandungan kuning telur merupakan makanan bagi larva sebelum dapat memakan makanan dari luar.

Ukuran telur berkorelasi dengan ukuran larva. Larva yang besar lebih tahan tanpa pakan dibandingkan dengan larva yang kecil yang ditetaskan dari telur yang kecil (Kamler 1992). Hubungan positif antara ukuran larva dan ukuran telur telah dilaporkan untuk Salmon salar, Onchorhynchus mykiss, dan turbot (Scopththalmus maximus. L) (Kjorsvik et al., 1990). Beberapa peneliti menunjukkan bahwa telur yang berukuran besar menghasilkan kelangsungan hidup yang lebih tinggi. Kamler (1992) mengajukan 
sebuah persamaan kelangsungan hidup untuk ikan pelagis laut, laju mortalitas telur dan larva berbanding terbalik dengan ukuran telur. Bila tidak ada makanan eksternal, larva yang lebih besar yang berasal dari telur yang besar dapat bertahan hidup lebih lama dibanding larva yang berasal dari telur yang kecil.

\section{KESIMPULAN}

Konsentrasi estradiol-17ß dalam plasma darah induk ikan selais betina sebelum induksi hormon Ovaprim berkisar 199,13 sampai 236,28 pg/mL sedangkan sesudah memijah berkisar 273,97 sampai $873,65 \mathrm{pg} / \mathrm{mL}$ dan rasio peningkatan konsentrasi estradiol-17 $\beta$ berkisar 64,61 sampai $657,90 \mathrm{pg} / \mathrm{mL}$ Konsentrasi testosteron dalam plasma darah induk ikan selais jantan sebelum induksi hormon Ovaprim berkisar 2,01 sampai $2,71 \mathrm{pg} / \mathrm{mL}$ sedangkan sesudah memijah berkisar 1,78 sampai 0,71 $\mathrm{pg} / \mathrm{mL}$ dan rasio penurunan konsentrasi testosteron berkisar 0,37 sampai 1,75 $\mathrm{pg} / \mathrm{mL}$. Penyuntikan hormon ovaprim 0,11 $\mathrm{mL} / 100$ gram berat induk merupakan dosis yang efektif dalam pemijahan buatan , mempercepat waktu laten pemijahan, fekunditas pemijahan, diameter telur, derajat pembuahan, penetasan telur dan kelangsungan hidup larva ikan selais

\section{SARAN}

Berdasarkan pada pertimbangan hasil penelitian, maka disarankan hormon ovaprim dapat merangsang keberhasilan pemijahan ikan selais pada dosis 0,11 $\mathrm{mL} / 100$ gram berat tubuh.

Perlu dilakukan penelitian lanjutan tentang pemberian pakan yang cocok dengan frekuensi dan dosis yang tepat tentang larva hasil pemijahan buatan yang diperoleh dari hasil penyuntikan ovaprim dosis $0,11 \mathrm{~mL} / 100$ gram

\section{UCAPAN TERIMA KASIH}

Penulis menyampaikan terima kasih kepada Bapak Prof. Dr. Ir. Usman M. Tang, MS dan Dr. Ir. Henni Syawal, M. Si. Yan telah membimbing dan membantu dalam penelitian ini. Terima kasih juga kepada semua pihak yang telah mambantu dalam penelitian ini.

\section{DAFTAR ACUAN}

Basuki F. 2007. Optimalisasi Pematangan Oosit dan Ovulasi pada Ikan Mas Koki (Carassius auratus) melalui Penggunaan Inhibitor Aromatase. Disertasi. Sekolah Pascasarjana. Institut Pertanian Bogor.

Budiman A, A.J. Arief dan A.H. Tjakrawidjaya. 2002. Peran Museum Zoologi Dalam Penelitian Dan Konservasi Keanekaragaman Hayati (Ikan). Jurnal Iktiologi Indonesia 2(2). Pusat Penelitian BiologiLembaga Ilmu Pengetahuan Indonesia (LIPI). Bogor

Brzuska E. 2006. Artificial Spawning Of Female Lithuanian Strain B Carp (Cypinus carpio L.) after treatment with carp pituitary homogenate, Ovopel or [dTleProNHEt9] GnRH-a (Lecirelin). Aquaculture Reseach. 37 (3): 264-271.

Denning-Kendall PA, Wathes DC, 1994. Acute Effects Of Prostaglandin F2 $\alpha$, Luteinizing Hormone, And Estradiol On Second Messenger Systems and On The Secretion Of Oxytocin And Progesterone From Granulosa And Earlyluteal Cells Of The Ewe. Biol. Reprod. 50, 765-773

Elvyra. R, Solihin.DD, Affandi. R, dan Junior.Z. 2010. Kajian Aspek Reproduksi Ikan Lais Ompok hypophthalmus di Sungai Kampar, Kecamatan Langgam, Kabupaten Pelalawan, Provinsi Riau. Jurnal Natur Indonesia 12(2) 
Effendie MI. 1997. Biologi Perikanan. Yayasan Pustakan Nusantara, Bogor.

Evans DH. 2000. The Physiology of Fishes. New York. CRC Press. Inc

Fujaya, Y. 2004. Fisiologi Ikan. Dasar Pengembangan Teknik Perikanan. Penerbit Rineka Cipta. Jakarta. 179 halaman.

I' tishom.R. 2008. Pengaruh sGnRH + Domperidon Dengan Dosis Pemberian Yang Berbeda Terhadap Ovulasi Ikan Mas (Cyprinus carpio L) train Punten. Departemen Biologi Kedokteran. Fak.Kedokteran Universitas Airlangga. Berkala Ilmiah Perikanan vol 3 no 1, hal 9-15.

Ismail MFS, Siraj SS, Daud SK, Harmin SA. 2011. Association of Annual Hormone Profile With Gonad Maturity of Mahseer (Tor Tambroides) In Captivity. General and Comparative Endocrinology, 170: 125-130.

Lahnsteiner F, Urbanyi B, Horvarth A and Weismann. 2001. Bio-markers for egg quality determination in cyprinid fish. Aquaculture 195: 331-352.

Lukas dan Minggawati, I. 2014. Presentase Jenis Makanan Dalam Lambung Ikan Lais Ompok hypopthalmus) Di Rawa Sungan Rungan, Kota Palangka Raya. Jurnal Ziraa'ah. 39(3):100-104.

Kjorsvik E, Mangor-Jensen A, Holmfjord I. 1990. Egg quality in fishes. Advances in Marine Biology, 26: 71-113.

MacKenzie DS, Thomas P, Farrar SM. 1989. Seasonal Changes In
Thyroid and Reproduction Steroid Hormones In Female Channel Catfish (Ichtalurus punctatus) In Pond Culture. Aquaculture, 78: 63 -80 .

Mahdaliana. 2014. Induksi ovulasi dan Pemijahan Semi Alami Pada Ikan Patin (Pangasianodon hypopthalmus) Menggunakan Kombinasi Hormon Aromatase Inhibitor dan Oksitosin. Tesis. Sekolah Pascasarjana Institut Pertanian Bogor

Nagahama Y. 1987b. 17a, 20ßdyhidroxy-4-pregnen-3-one: a teleost maturation inducing hormone. Develop. Growth and Differ. 29(1):1-12

Nuraini, Alawi H, Nurasiah dan Aryani N. 2013. Pengaruh sGnRH + Domperidon Dengan Dosis Yang Berbeda Terhadap Pembuahan Dan Penetasan Telur Ikan Selais (Ompok rhadinurus Ng). Jurnal Perikanan dan Kelautan UNRI.

Oyen FGF, LEC Campr and ESW Bongo. 1991. Effects of Acid Stress on the Embryonic Development of the Common Carp, Cyprinus carpio L. J Aquat Toxicology 19:1-12.

Putra, I., Mulyadi, Pamukas, A.N. dan Rusliadi. 2013. Peningkatan Kapasitas Produksi Akuakultur Pada Pemeliharaan Ikan Selais (Ompok sp.) Sistem Aquaponik. Jurnal Perikananan dan Kelautan (1): 01-10.

Simanjuntak, C.P.H., M. F. Rahardjo, dan Sjafei. DS. 2008. Perkembangan Kematangan Gonad Dan Tipe Pemijahan Ikan Selais (Ompok hypophthalmus) di Rawa Banjiran Sungai Kampar Kiri, Riau. Journal iktiologi Indonesia. 
Subagja J., R. Gustiano., 2006. Pengaruh Implantasi hcg Pada Perkembangan Telur, Pematangan Akhir Gonad, Dan Pemijahan Ikan Tor Soro. Jurnal Riset Akuakultur 1:219-225.

Sudrajat AO. 2012. Pengantar Endokrinologi. Materi mata kuliah Endokrinologi. Institut pertanian Bogor

Rottmann RW, Shireman JV, Chapman FA. 1991. Hormonal Control Of Reproduction In Fish For Induced Spawning. Srac publication no. 424. United States Departemen of Agriculture.

Yaron Z. 1995. Endocrine Control Of Gametogenesis and Spawning
Induction In The Carp. Aquaculture, $129: 49-73$.

Zairin Jr M. Furukawa, Aida K. 1992. Induction of Ovulation by $\mathrm{HCG}$ Injection in Tropical Walking Catfish, Clarias bsatrachus Reared Under 23-250C. Nippon Suisan Gakkaishi, 58(a): 1681 - 1685.

Zairin Jr M. 2003. Endokrinologi dan Perannya Bagi Masa Depan Perikanan Indonesia. Orasi ilmiah. Fakultas Perikanan dan Ilmu Kelautan Institut Pertanian Bogor.

\section{Email :}

ismail.nasril@yahoo.com usmanmt@yahoo.co.id heni_ifoid@yahoo.com 